\title{
Spinal Block Anesthesia With Morphine in a Hemorrhoidectomy
}

\author{
Byung Chun Kim \\ Department of Surgery, Hallym University Kangnam Sacred Heart Hospital, Hallym University College of Medicine, Seoul, Korea
}

See Article on Page 135-140

An optimal dose of intrathecal morphine to reduce pain after a hemorrhoidectomy is $0.1-2.5 \mathrm{mg}$. However, the risks and the side effects of intrathecal morphine include nausea, vomiting, pruritus, urinary retention and respiratory depression [1]. Recently, a low dose (0.1-0.25 mg) of intrathecal morphine has been used to reduce the possible complications and side effects of morphine [1]. Spinal anesthesia with such a low dose of morphine has proven to be safe and effective for a hemorrhoidectomy [2], Caesarean section [3], tubal ligation [4], transurethral prostatectomy [5] and orthopedic surgery [6]. The biggest challenge in a hemorrhoidectomy is to control pain after surgery. Pain usually lasts for at least a few days or weeks after a hemorrhoidectomy. The reasons patients are reluctant to undergo a hemorrhoidectomy include postoperative pain, behavioral disorder and anal discharge. Among them, postoperative pain was ranked the number one reason. Several solutions including the procedure for prolapses and hemorrhoids have been devised to reduce pain after a hemorrhoidectomy [7], but other alternatives exist. Several factors, such as the anesthesia method, the dissection method of anal tissues, the number of excised piles and patient-controlled anesthesia, can be taken into consideration to reduce pain after a traditional hemorrhoidectomy procedure.

This study conducted a comparative analysis on the pain and the complications that occurred within 24 hours after surgery between the morphine-addition group and the non-morphine-addition group. Postoperative pain in the morphine-addition group was remarkably reduced compared to that in the non-morphine-

Correspondence to: Byung Chun Kim, M.D.

Department of Surgery, Kangnam Sacred Heart Hospital, Hallym University College of Medicine, 1 Singil-ro, Yeongdeungpo-gu, Seoul 150-950, Korea

Tel: +82-2-829-5130, Fax: +82-2-849-4469

E-mail: bckimgs@hallym.or.kr

(c) 2014 The Korean Society of Coloproctology

This is an open-access article distributed under the terms of the Creative Commons Attribution NonCommercial License (http://creativecommons.org/licenses/by-nc/3.0) which permits unrestricted noncommercial use, distribution, and reproduction in any medium, provided the original work is properly cited. addition group at 6,12 , and 24 hours after surgery. However, the morphine-addition group showed a significant increase in postoperative complications, such as pruritus and urinary retention [8]. Therefore, although it is effective in reducing short-term pain which can occur within 24 hours after surgery, the spinal block anesthesia with morphine must be performed in consideration of possible complications such as pruritus, urinary retention, hypotension and respiratory depression. Also, more studies need to be carried out on clinical effects of morphine. If we can employ a method that can prevent complications or side-effects after a hemorrhoidectomy and control pain on a long-term basis, we can make a patient feel more comfortable, reduce the duration of hospitalization, save medical expenses and reduce behavioral disorders after surgery.

\section{REFERENCES}

1. Gehling M, Tryba M. Risks and side-effects of intrathecal morphine combined with spinal anaesthesia: a meta-analysis. Anaesthesia 2009;64:643-51.

2. Amanor-Boadu SD. Assessment of minidose intrathecal morphine for analgesia after hemorroidectomy. West Afr J Med 1992; 11:146-9.

3. Abboud TK, Dror A, Mosaad P, Zhu J, Mantilla M, Swart F, et al. Mini-dose intrathecal morphine for the relief of post-cesarean section pain: safety, efficacy, and ventilatory responses to carbon dioxide. Anesth Analg 1988;67:137-43.

4. Campbell DC, Riben CM, Rooney ME, Crone LA, Yip RW. Intrathecal morphine for postpartum tubal ligation postoperative analgesia. Anesth Analg 2001;93:1006-11.

5. Cunningham AJ, McKenna JA, Skene DS. Single injection spinal anaesthesia with amethocaine and morphine for transurethral prostatectomy. Br J Anaesth 1983;55:423-7.

6. Kalso E. Effects of intrathecal morphine, injected with bupivacaine, on pain after orthopaedic surgery. Br J Anaesth 1983;55: 415-22.

7. Ganio E, Altomare DF, Milito G, Gabrielli F, Canuti S. Long-term outcome of a multicentre randomized clinical trial of stapled haemorrhoidopexy versus Milligan-Morgan haemorrhoidectomy. 


\section{Coloproctology}

Byung Chun Kim

Br J Surg 2007;94:1033-7.

8. Moreira H Jr, Moreira JP, Isaac RR, Alves-Neto O, Moreira TA, Vieira TH, et al. Morphine spinal block anesthesia in patients who undergo an open hemorrhoidectomy: a prospective analysis of pain control and postoperative complications. Ann Coloproctol 2014;30:135-40. 